\title{
Review and Prospect of Mindfulness Training for Intervention of Academic Burnout
}

\author{
Xingyu Ding; Jianxuan Tang \\ School of Humanities \\ Jiangxi University of Traditional Chinese Medicine \\ Nanchang City, China \\ 602374057@qq.com; 279771880@qq.com
}

\author{
Zhibing Zhong* \\ Psychological Counseling Center \\ Jiangxi University of Traditional Chinese Medicine \\ Nanchang City, China \\ 494234679@qq.com
}

\begin{abstract}
Academic burnout involves the negative emotions of exhaustion and evasion caused by excessive academic load, low sense of accomplishment, and cynicism for studies. It has gradually become a psychological crisis for many contemporary students. Purpose: This paper attempts to summarize the research results of mindfulness training for intervention of academic burnout and propose prospects for future related research. Methods: Review the past experimental studies on mindfulness intervention in academic burnout, summarize the methods used in previous studies, and compare the results obtained. Conclusion: Even if mindfulness training has a certain intervention effect on academic burnout, there are still areas for improvement in future research: (1) The research methods are insufficient. Specifically, the RCT design is not rigorous, the indicators of intervention effect are relatively simple, and the number of longitudinal studies is not enough. (2) Further research is required to explore effective academic burnout interventions for different student groups.
\end{abstract}

Keywords-mindfulness training; academic burnout; intervention; experimental study

\section{INTRODUCTION}

Academic burnout, a derivative of burnout, was first proposed by Pines et al. (1981). It refers to negative emotions of exhaustion and evasion caused by excessive academic load, low sense of accomplishment, and cynicism for studies ${ }^{[1]}$. Ni, Ma \& Li (2012) conducted a survey of 439 students in China, and the results showed that about $80.7 \%$ of students reported problems with academic burnout ${ }^{[2]}$. Students' academic burnout is a problem that cannot be ignored in modern society. Negative emotions such as anxiety, depression and low selfefficacy caused by academic burnout have made more and more students fall into a vicious circle manifested by low academic achievement-low mood-inappropriate behavior-low academic achievement. Many people ended up by choosing indifferent or even giving themselves up in their studies, and what is more serious is that some students are so stressed with studies that they behave extremely (e.g. suicide). Therefore, it is of great significance to study how to intervene in college students' academic burnout.

Mindfulness (called "Sati" in Buddhism) is derived from the Buddhist text "Si Nian Su Jing", which belongs to the core
Zen method of primitive Buddhism. It emphasizes focusing on the present and accepting it peacefully. Through mindfulness, people can effectively get rid of the inner desires, anxiety and distracting thoughts, thereby increasing concentration and stabilizing the mood ${ }^{[3]}$. At present, the academic community has not reached a consensus on the exact definition of mindfulness. Based on the Chinese and foreign literatures ${ }^{[4]}{ }^{[5]}$ [6], we believe that the mindfulness has the following characteristics: (1) Attention to current moment; (2) No assessment on the current idea; (3) acceptance. Mindfulness training is a kind of psychological intervention that absorbs the idea of oriental Buddhism. Common methods include mindfulness decompression therapy (MBSR) and mindfulness cognitive therapy (MBCT), which have been widely used in the field of psychology. Good results have been achieved in intervening in mental and physical problems. Studies have shown that mindfulness decompression therapy is an effective method to interfere with the students' academic burnout ${ }^{[7]}$. In addition, mindfulness-based therapies include acceptance and commitment therapy (ACT) and dialectical behavioral therapy (DBT). This paper attempts to summarize the research results of mindfulness training for intervention of academic burnout and propose prospects for future related research.

As of June 13, 2019, there are 111 papers published in Chinese with "mindfulness" or "Vipassana", "mindfulness training" and "study burnout" or "study", "stress" as the keywords in Chinese-language databases such as Chinese Knowledge Network, VIP, Wanfang data. There are 165 papers published in English with the keywords of "mindfulness" or "MBSR", "MBCT" and "academic burnout" or "academic" and "stress" in foreign language databases EBSCO, Springer Link, Elsevier, ProQuest, and Wiley. We then screened and removed any duplicated. We selected papers based on the following criteria: (1) the study was published in Chinese and English; (2) the study involved a mindfulness-based intervention for academic burnout or academic bad moods; (3) exclusion of relevant research and research without data (including research papers not published and incomplete data in conference proceedings).

Project supported by the subject of General Administration of Sport of China (QG2016029)

*Corresponding author: Zhibing Zhong, Email: 494234679@qq.com 
TABLE I.

\begin{tabular}{|c|c|c|c|c|c|}
\hline $\begin{array}{l}\text { Authors \& } \\
\text { Years }\end{array}$ & Intervention Group & Control group & Result & What's Special & $\begin{array}{l}\text { Whether the } \\
\text { Tracking }\end{array}$ \\
\hline $\begin{array}{l}\text { Ye Xin et al., } \\
2017^{[8]}\end{array}$ & $\begin{array}{l}\mathrm{n}=30,2 \text {-week group } \\
\text { mindfulness training, } \\
5.5 \mathrm{~h} / \text { week }\end{array}$ & $\begin{array}{l}\mathrm{n}=30 \text {, No } \\
\text { intervention }\end{array}$ & $\begin{array}{l}\text { The level of academic burnout in the } \\
\text { experimental group was significantly } \\
\text { improved; No significant improvement was } \\
\text { found in the control group }\end{array}$ & $\begin{array}{l}\text { RCT design; 2- } \\
\text { week short } \\
\text { intervention }\end{array}$ & No \\
\hline $\begin{array}{l}\text { Su Kewei et al., } \\
2019^{[9]}\end{array}$ & $\begin{array}{l}\mathrm{n}=12,8 \text {-week group } \\
\text { mindfulness training, } \\
\text { 2h/week }\end{array}$ & $\begin{array}{l}\mathrm{n}=12, \mathrm{No} \\
\text { intervention }\end{array}$ & $\begin{array}{l}\text { The situation of college students' academic } \\
\text { burnout was significantly improved, and the } \\
\text { improvement effect was maintained with time }\end{array}$ & $\begin{array}{l}\text { A follow-up } \\
\text { survey was } \\
\text { designed }\end{array}$ & $\begin{array}{l}\text { Yes, at } 3 \text { months } \\
\text { and } 5 \text { months after } \\
\text { intervention }\end{array}$ \\
\hline $\begin{array}{l}\text { Zhang Ting, } \\
2015^{[10]}\end{array}$ & $\begin{array}{l}\mathrm{n}=11, \text { 5-week MBSR, } \\
\text { 1h/week. }\end{array}$ & $\begin{array}{l}\text { No control } \\
\text { group }\end{array}$ & $\begin{array}{l}\text { The level of academic burnout in the } \\
\text { experimental group was significantly lower } \\
\text { than that in the control group }\end{array}$ & $\begin{array}{l}\text { Use the MBSR } \\
\text { way, no control } \\
\text { group }\end{array}$ & No \\
\hline $\begin{array}{l}\text { Su Liping, } \\
2016^{[11]}\end{array}$ & $\begin{array}{l}\mathrm{n}=15,8 \text {-week group } \\
\text { mindfulness training, } \\
\text { 2h/week }\end{array}$ & $\begin{array}{l}\text { No control } \\
\text { group }\end{array}$ & $\begin{array}{c}\text { The academic delay of the subjects was } \\
\text { significantly improved, and the improvement } \\
\text { effect was maintained over time }\end{array}$ & $\begin{array}{c}\text { A follow-up } \\
\text { survey was } \\
\text { designed } \\
\end{array}$ & $\begin{array}{l}\text { Yes, at } 2 \text { months } \\
\text { after intervention }\end{array}$ \\
\hline $\begin{array}{l}\text { Zhao Mengyin, } \\
\qquad 2019^{[7]}\end{array}$ & $\begin{array}{l}\mathrm{n}=25 \text {, 8-week group } \\
\text { MBSR, 1.5h/week }\end{array}$ & $\begin{array}{l}\mathrm{n}=25 \text {, no } \\
\text { intervention }\end{array}$ & $\begin{array}{l}\text { The level of academic burnout in the } \\
\text { experimental group was significantly } \\
\text { improved, while that in the control group was } \\
\text { not significantly improved after intervention }\end{array}$ & RCT design & No \\
\hline $\begin{array}{l}\text { Juliane et al., } \\
2017^{12]}\end{array}$ & $\begin{array}{l}\mathrm{n}=51,10 \text {-week MBSLT } \\
\text { training, } 1 \text { session per } \\
\text { week }\end{array}$ & $\begin{array}{l}\mathrm{n}=58, \text { no } \\
\text { intervention }\end{array}$ & $\begin{array}{l}\text { The experimental group showed significant } \\
\text { improvement in academic stress and anxiety, } \\
\text { academic self-efficacy and academic } \\
\text { achievement compared with the control group }\end{array}$ & RCT design & No \\
\hline Mark, 2011 $1^{[13]}$ & $\begin{array}{l}\mathrm{n}=5,6 \text {-session of } \\
\text { modify MBCT, } 1 \mathrm{~h} \text { per } \\
\text { session }\end{array}$ & $\begin{array}{l}\text { no control } \\
\text { group }\end{array}$ & $\begin{array}{c}\text { Four of the five nursing students who } \\
\text { received the intervention had reduced stress } \\
\text { levels }\end{array}$ & $\begin{array}{l}\text { Single-subject } \\
\text { design and small } \\
\text { sample size }\end{array}$ & No \\
\hline $\begin{array}{l}\text { Vibe et al., } \\
2013^{[14]}\end{array}$ & $\begin{array}{l}\mathrm{n}=144,7 \text {-week MBSR } \\
\text { ( } 2 \mathrm{~h} \text { per week for the } \\
\text { first } 6 \text { weeks and } 6 \mathrm{~h} \text { for } \\
\text { the seventh week) }\end{array}$ & $\begin{array}{l}\mathrm{n}=144, \text { no } \\
\text { intervention }\end{array}$ & $\begin{array}{l}\text { Female subjects' mental distress, learning } \\
\text { pressure, subjective well-being, mindfulness } \\
\text { and other aspects have significantly } \\
\text { improved. There was no significant } \\
\text { improvement in academic burnout among all } \\
\text { students. }\end{array}$ & $\begin{array}{l}\text { RCT design, The } \\
\text { results considered } \\
\text { demographic } \\
\text { variables }\end{array}$ & No \\
\hline $\begin{array}{l}\text { Steven et al., } \\
\quad 2003^{[15]}\end{array}$ & $\begin{array}{l}\mathrm{n}=140,10 \text {-week } \\
\text { MBSR, 1.5h per week }\end{array}$ & $\begin{array}{c}\mathrm{n}=162, \\
\text { complementary } \\
\text { and alternative } \\
\text { medicine }\end{array}$ & $\begin{array}{l}\text { Students in the intervention group had } \\
\text { significantly lower stress after intervention. }\end{array}$ & $\begin{array}{l}\text { The control group } \\
\text { used an alternative } \\
\text { course }\end{array}$ & No \\
\hline $\begin{array}{l}\text { Annie et al., } \\
2015^{[16]}\end{array}$ & $\begin{array}{l}\mathrm{n} 1=13, \mathrm{n} 2 \mathrm{a}=14,4 \text {-week } \\
\text { mindfulness meditation, } \\
1 \mathrm{~h} / \text { week; } \mathrm{n} 2 \mathrm{~b}=12,4- \\
\text { week de-stress with } \\
\text { dogs' group, 1h/week }\end{array}$ & $\begin{array}{l}\text { n1=13, 4-week } \\
\text { de-stress with } \\
\text { dogs' group, } \\
\text { 1h/week;n2=22 } \\
\text {, no } \\
\text { intervention }\end{array}$ & $\begin{array}{l}\text { After intervention, the anxiety level of the } \\
\text { mindfulness group and the dog group was } \\
\text { significantly lower than that of the control } \\
\text { group, and the improvement level of the } \\
\text { mindfulness group was the most obvious. The } \\
\text { HRV of the mindfulness group was } \\
\text { significantly higher than that of the other two } \\
\text { groups }\end{array}$ & $\begin{array}{l}2 \text { RCT design, } \\
\text { including } 3 \\
\text { groups; Takes the } \\
\text { HRV as one of the } \\
\quad \text { indicators }\end{array}$ & No \\
\hline $\begin{array}{l}\text { Chen Cuicui et } \\
\text { al., 2019 }\end{array}$ & $\begin{array}{l}\mathrm{n}=14,8 \text {-week } \\
\text { mindfulness training, } \\
\text { 2h/week }\end{array}$ & $\begin{array}{l}\mathrm{n}=14, \text { no } \\
\text { intervention }\end{array}$ & $\begin{array}{l}\text { The attention and academic mood of the } \\
\text { students were significantly improved, and the } \\
\text { improvement effect of the experimental group } \\
\text { was significantly better than that of the } \\
\text { control group }\end{array}$ & RCT design & No \\
\hline $\begin{array}{l}\text { Puolakanaho et } \\
\text { al., } 2018^{[18]}\end{array}$ & $\begin{array}{l}\mathrm{n}=161,5 \text {-week online } \\
\text { ACT, } 1.5 \mathrm{~h} \text {-3h per week }\end{array}$ & $\begin{array}{l}\mathrm{n}=82, \text { no } \\
\text { intervention }\end{array}$ & $\begin{array}{l}\text { Academic skills did not influence the } \\
\text { intervention gains, but the intervention gains } \\
\text { were largest among high-stressed participants. }\end{array}$ & $\begin{array}{l}\text { RCT design, } 2 \\
\text { conditions in the } \\
\text { intervention group }\end{array}$ & No \\
\hline $\begin{array}{l}\text { Barbosa et al., } \\
2013^{[19]}\end{array}$ & $\begin{array}{l}\mathrm{n}=13 \text {, 8-week MBSR } \\
\text { course, } 2.5 \mathrm{~h} / \text { week }(1 \mathrm{~h} \\
\text { during the } 6 \text { th week) } \\
\text { and } 40 \text { min daily } \\
\text { practice }\end{array}$ & $\begin{array}{l}\mathrm{n}=15 \text {, no } \\
\text { intervention }\end{array}$ & $\begin{array}{l}\text { Significant decrease in anxiety compared with } \\
\text { baseline was observed; Significant increase in } \\
\text { empathy after intervention was observed; No } \\
\text { significant differences in burnout scores } \\
\text { between those in the intervention and control } \\
\text { groups. }\end{array}$ & $\begin{array}{l}\text { A follow-up } \\
\text { survey was } \\
\text { designed }\end{array}$ & $\begin{array}{l}\text { Yes, at } 3 \text { weeks } \\
\text { after intervention }\end{array}$ \\
\hline
\end{tabular}

Finally, 6 Chinese papers and 7 English papers were selected. Table 1 summarizes the information from the selected papers.

\section{RESEARCH METHODS OF MiNDFULNESS INTERVENTION FOR ACADEMIC BURNOUT}

\section{A. RCT Experiment is the Main Method}

It can be seen from Table I that the RCT design of mindfulness intervention in academic burnout accounts for the heaviest proportion (about 54\%) in all research designs. This 
experimental method can largely balance the confounding factors and improve the validity of statistical tests. The earliest searchable RCT-designed experiments in this field were published in 2013 by Vibe et al., which examined the effects of mindfulness training on stress management in medical and psychology students. It is worth mentioning that the study took the demographic variables into consideration, which presented gender difference in the evaluation of the effect of mindfulness in the intervention of stress, thus bringing about challenge for the future research on the intervention of academic burnout.

In the literature listed in Table 1, there are two RCT designs with multiple experimental scenarios. Annie et al. even set up two RCT programs with three experimental scenarios; Puolakanaho et al. set up two intervention approach in an RCTdesigned intervention group. In addition to the RCT experiment, other studies have used other methods to control additional variables, allowing subjects to be homogeneous at baseline. For example, Su Kewei et al. used the matching method to assign experimental and control group participants, so that the two groups before the intervention could maintain consistency in terms of gender, age, professional type, mindfulness perception score and academic burnout score, thus increasing the persuasive effect of the intervention.

\section{B. Control Group Adopts Active Control}

As can be seen from Table 1, most of the experimental control groups were designed not to give any intervention, and there are only 2 publicly published studies using active control groups. Setting up an active control group can avoid misjudgment of experimental results due to self-healing, historical trends, and regression to average or expected effects. This helps further clarify the efficacy of the interventions used in the study and increase the reliability and validity of the results. The earliest study that used an active control group in the field was published by Steven et al. in 2003. In that study, participants in the control group were required to participate in a complementary and alternative medicine course. The course only introduced physical and mental skills to the subjects, without training to the subjects, which demonstrated the efficacy of MBSR training in reducing the stress level of the intervention group. Puolakanaho et al. even set up the experimental group, the active control group ('de-stress with dogs' group) and the passive control group (without any intervention) in the second experiment, and the results were compared under this premise. With these types of manipulations, the efficacy of the intervention can be properly evaluated, and the results of the experiment can be more convincing.

\section{Use Comprehensive Psychophysiological Indicators as an Assessment Tool}

In the above listed literatures, about $93 \%$ of the measurement tools used in the experiments are self-reported scales or questionnaires, such as the Chinese version of the academic burnout scale (Lian et al. 2005), Academic Buoyancy Scale (Martin \& Marsh, 2008), and Beck Depression Inventory (BDI-II; Beck, Steer, \& Brown, 1996). Most of the factors that rely on mindfulness to interfere with academic burnout are psychological indicators. Only one study (Annie et al.) introduced HRV in the experimental design and used a psychological scale to evaluate the mindfulness meditation. HRV refers to changes in the heartbeat (R-R) intervals and is an important indicator for measuring the relationship between brain, body, stress and health associated with nerves ${ }^{20]}$ (Lewis et al., 2015). Compared with the use of psychology as single indicator, comprehensive use of psychophysiological indicators as an assessment approach can make the experimental results more objective.

\section{THE EFFECT OF MindFULNESS TRAINING ON ACADEMIC BURNOUT}

\section{A. Analysis of the Effectiveness of Intervention}

Overall, most of the published experimental studies of mindfulness intervention in academic burnout show that mindfulness can effectively reduce academic burnout (including other negative academic behaviors and feelings). For example, Julian et al. found that the subject's academic self-efficacy was significantly improved after the intervention by mindfulness, with an effective amount $d=0.54$. However, a few studies have shown that the effect of mindfulness intervention is not significant to some dimensions or different demographic variables. As shown by Vibe et al. and Barbosa et al., there was no significant change in academic burnout among all students before and after the mindfulness intervention $(p>0.05)$. In addition, we can see that the mindfulness intervention used in 12 papers differed in the form and cycle of intervention, with a maximum of 10 weeks and a minimum of 2 weeks, and most of the results suggest that the intervention effect is significant.

In summary, the mindfulness intervention in academic burnout is effective to a certain extent and is not subject to the length of the intervention cycle and the form of intervention.

\section{B. Intervention Effects are Affected by Internal and External Factors}

Although in general, mindfulness training has a certain interventional effect on academic burnout, which types of students benefit and how effective the interventions are cannot be determined at this point. For example, the results of Vibe et al. showed that boys had no significant difference in mental pain, academic stress and psychosomatic health index, while girls showed significant differences, suggesting that the effect of mindfulness intervention is susceptible to internal factors such as sex differences in subjects. Su Kewei et al. found that the scores of the burnout in the experimental group showed a trend of decreasing first and then increasing, although it may be due to the fact that the last test was close to the final exam, and the experimental group lacked the mindfulness training, which also indicated that the interfering effect of mindfulness on academic burnout is influenced by external factors (e.g. exams) and internal factors (e.g. test practice time). 


\section{LIMITATIONS AND PROSPECTS FOR THE RESEARCH}

\section{A. Gradually Improve the Preciseness of RCT Design}

Although RCT is a very good experimental design, and the above 13 RCT designs account for a large proportion, some of the experimental designs are still not precise. First, only two of the seven RCT studies (Vibe et al. and Puolakanaho et al.) clearly showed how the subjects for experimental control group were randomly assigned, and the others did not specify the specific procedures and programs for assigning subjects to experimental and control groups. If the methodological aspects are not precise, there might be a bias for RCT ${ }^{[21]}$. In future research, attention should be paid to clarifying the methods used to randomly assign subjects, rather than simply in a short sentence. Secondly, in the seven RCT experimental studies, all Chinese literature did not report the effect of mindfulness intervention, and foreign literature did a good job in this regard, which is also what Chinese scholars need to improve in future research.

\section{B. Use Multidimensional Indicators as the Measurement for Intervention Effect}

Of all the above literature, only one study introduced the physiological index of HRV into the experiment, together with the psychological indicators as the basis for observing intervention effect. Since the psychological indicators are mostly measured by the self-reported scale, the measurement results are easily affected by the subjective willing of the subject, while the physiological indicators reflect an objective numerical value. When the additional variables are controlled, more objective experimental results can be obtained. The use of multidimensional indicators as a measurement for intervention effect can increase the persuasiveness and reliability of experimental results. With the development of technology, the previous physiological data which was difficult to get (e.g. heart rate, blood pressure) can now be easily collected through smart wearable devices (e.g. Nike FuelBand).

A review of He Yuanqing et al. for studies on the mindfulness intervention of job burnout shows that physiological indicators used to measure mindfulness intervention in burnout include salivary cortisol, blood pressure, salivary alpha amylase, reactive oxygen metabolite compounds (d-roms) and biological antioxidant potential (BAP). In addition to psychological and physiological indicators, behavior indicators (e.g. absence time, work performance) are also used as one of the reference variables. Therefore, future research on mindfulness intervention in academic burnout should not be limited to the use of single indicator as a basis for observing intervention effects.

\section{Gradually Increase Longitudinal Study}

The longitudinal study refers to a method that investigates the same group of subjects at different time, collecting data, and then exploring the changes of certain (social) phenomena over time as well as the consequences between different phenomena by statistical analysis of the data obtained from several previous and subsequent surveys[22]. There are currently only 3 papers published in this field which added follow-up test (Su Kwei et al., Su Liping, Barbosa et al.), but the follow-up only lasted for 5 months. The reason why most of the studies are not followed up is because the subjects themselves have been tested for the pre and post test. If any longitudinal study is carried out, it is easy to produce a practice effect or a fatigue effect on the test, which reduces the degree of cooperation, thus affecting the reliability and validity of the tracking results. If the longitudinal study is not carried out, the long-term effect of mindfulness intervention in academic burnout will not be strong and persuasive, and it will also make it difficult to observe the trajectory of intervention effects over time. To solve this problem, researchers need to think about how to overcome the above problems in the future, in order to gradually increase the number of longitudinal studies in this research field.

\section{Increase Intervention Research on Different Groups}

At present, unlike the studies on career burnout, the study of an intervention in school burnout rarely divides students into different groups (e.g. different occupations) to conduct targeted intervention tests, which leads to the inability to grasp the difference in the effect of mindfulness on diverse student populations. Current mindfulness interventions are not shown to be effective for a specific problem in a specific student group. For example, studies have shown that students with low self-core evaluation and low level of mindfulness are more prone to academic burnout, with Cohen's $d$ of -0.5 and -0.47 respectively ${ }^{[23]}$. The results of this study indirectly indicate that students with more positive psychology are less prone to academic burnout. Even if academic burnout appears, they are more likely to be interfered, while students with negative traits are more likely to suffer from academic burnout. There is no study yet on intervening in the academic burnout of these students with mindfulness intervention. This means that future research should focus on interventions for people with susceptibility to burnout.

\section{CONCLUSION}

In summary, there is evidence that the mindfulness training for intervention of academic burnout can be effective. However, there are still some shortcomings in current research. The first is the lack of research methods. Specifically, the RCT experimental design needs to be more rigorous, the measurement of the intervention effect should integrate psychophysiological and behavioral indicators, and there should be more longitudinal studies. The second is the lack of research with different student populations. In the future, it is necessary to increase the intervention research of different student groups (e.g. different academic qualifications, different majors, different genders) in order to maximize the social and economic benefits of mindfulness training for intervention of academic burnout.

\section{REFERENCES}

[1] Ayala. M. Pines, Elliot Aronson and Diska Kafry, "Burnout: From Tedium to Personal Growth,” Free press, New York, 1981.

[2] Ni S., Ma H., Li H., "Research on the Academic Burnout of Chinese University Students,” In: Yang Y., Ma M. (eds) Proceedings of the 2nd 
International Conference on Green Communications and Networks 2012 (GCN 2012): Volume 2. Lecture Notes in Electrical Engineering, 2013, pp.459-468.

[3] Yang Yuwen, "Mindfulness training on irritable bowel syndrome quality of life and anxiety effect," [D]. Minnan Normal University, 2015. (In Chinese)

[4] Kabat-Zinn, Jon, "Mindfulness-Based Interventions in Context: Past, Present, and Future,” 10.2(2003), pp.144-156, 2003.

[5] Bodhi, and Bhikkhu, "What does mindfulness really mean? A canonical perspective,” Contemporary Buddhism 12(1), pp.19-39, 2011.

[6] He YuanQing, Lian Rong. Review of mindfulness training intervention on job burnout [J]. Journal of Fujian Normal University (Philosophy and Social Sciences Edition), 2018, 213(06): 84-92+175. (In Chinese)

[7] Zhao Mengyin, Cao Yunhua, "Experimental study on improving academic burnout of medical students with mindfulness decompression therapy [J]. The Fortune Times, 3(2019):243-243. (In Chinese)

[8] Ye Xin, Lin Xianhao, Zhou Yaoyao. The effect of group mindfulness practice on the learning burnout of college students [J]. Journal of Fujian Medical University (Social science Edition), 2017(2). (In Chinese)

[9] Kewei, Zhou Hang, Li Bo. The effects of mindfulness group training on improving college students' learning burnout [J]. China Journal of Health Psychology, 27.02(2019):66-71. (In Chinese)

[10] Zhang Ting. Mindfulness-Based stress reduction for high school students’ academic burnout [D]. Northwest Normal University, 2015. (In Chinese)

[11] Su Liping. Intervention Study of Mindfulness Training on Middle School Students' Academic Procrastination [D]. Chongqing Normal University, 2016. (In Chinese)

[12] Sampl, Juliane, T. Maran, and M. R. Furtner, "A Randomized Controlled Pilot Intervention Study of a Mindfulness-Based SelfLeadership Training (MBSLT) on Stress and Performance," Mindfulness (2017).

[13] Schwarze M J. Assessing the Effectiveness of Mindfulness-Based Cognitive Therapy in Individual Sessions in Reducing Self-Reported Stress and Increasing Self-Reported Mindfulness Levels of a Nursing Student [J]. Dissertations \& Theses - Gradworks, 2012.
[14] Vibe M D, Solhaug I, Tyssen R, et al. Mindfulness training for stress management: A randomized controlled study of medical and psychology students [J]. BMC Medical Education, 2013, 13(1):107.

[15] Rosenzweig S, Reibel D K, Greeson J M, et al. Mindfulness-Based Stress Reduction Lowers Psychological Distress in Medical Students[J]. Teaching and Learning in Medicine, 2003, 15(2):88-92.

[16] Shearer A, Hunt M, Chowdhury M, et al. Effects of a Brief Mindfulness Meditation on Student Stress and Heart Rate Variability [J]. 2016.

[17] Chen Cuicui, Du Xiaoxin, Li Ye-e. Effect of Mindfulness Training on Attention and Academic Emotion of Students with Learning Disabilities [J]. Journal of Schooling Studies, 2019,16(02):74-81. (In Chinese)

[18] Puolakanaho A, Lappalainen R, Lappalainen, Päivi, et al. Reducing Stress and Enhancing Academic Buoyancy among Adolescents Using a Brief Web-based Program Based on Acceptance and Commitment Therapy: A Randomized Controlled Trial[J]. Journal of Youth and Adolescence, 2018

[19] Barbosa P, Raymond G, Zlotnick C, et al. Mindfulness-based stress reduction training is associated with greater empathy and reduced anxiety for graduate healthcare students[J]. Education for Health Change in Learning \& Practice, 2013, 26(1):9-14.

[20] Lewis G F, Hourani L, Tueller S, et al. Relaxation training assisted by heart rate variability biofeedback: Implication for a military predeployment stress inoculation protocol[J]. Psychophysiology, 2015, 52(9):1167-1174.

[21] Qiu Xia, Zhang Pan, Zhang Huihui, Ge Long, Pei Gaiqin et al. Quality assessment of reports of randomized control trials published in Chinese in field of non-small cell lung cancer in China [J]. Chinese Journal of Medical Library and Information Science, 2016(02). (In Chinese)

[22] Feng Xiaotian. Panel Study: Methodological Significance and Implement [J]. Journal of Huazhong Normal University (Humanities and Social Sciences) 2006, 45(6):43-47. (In Chinese)

[23] Liu Peipei, Lv Liming, Wang Shuo, Yang Xinyu, Zhu Lijing, Cheng Haiying. Mediating Effect of Core Self-evaluation on Mindfulness and Academic Burnout among Nursing Students [J]. Journal of Nursing (China), 2019,26(08):41-45. (In Chinese) 